\title{
Gazetteer of Hydrologic Characteristics of Streams in Massachusetts--Blackstone River Basin
}

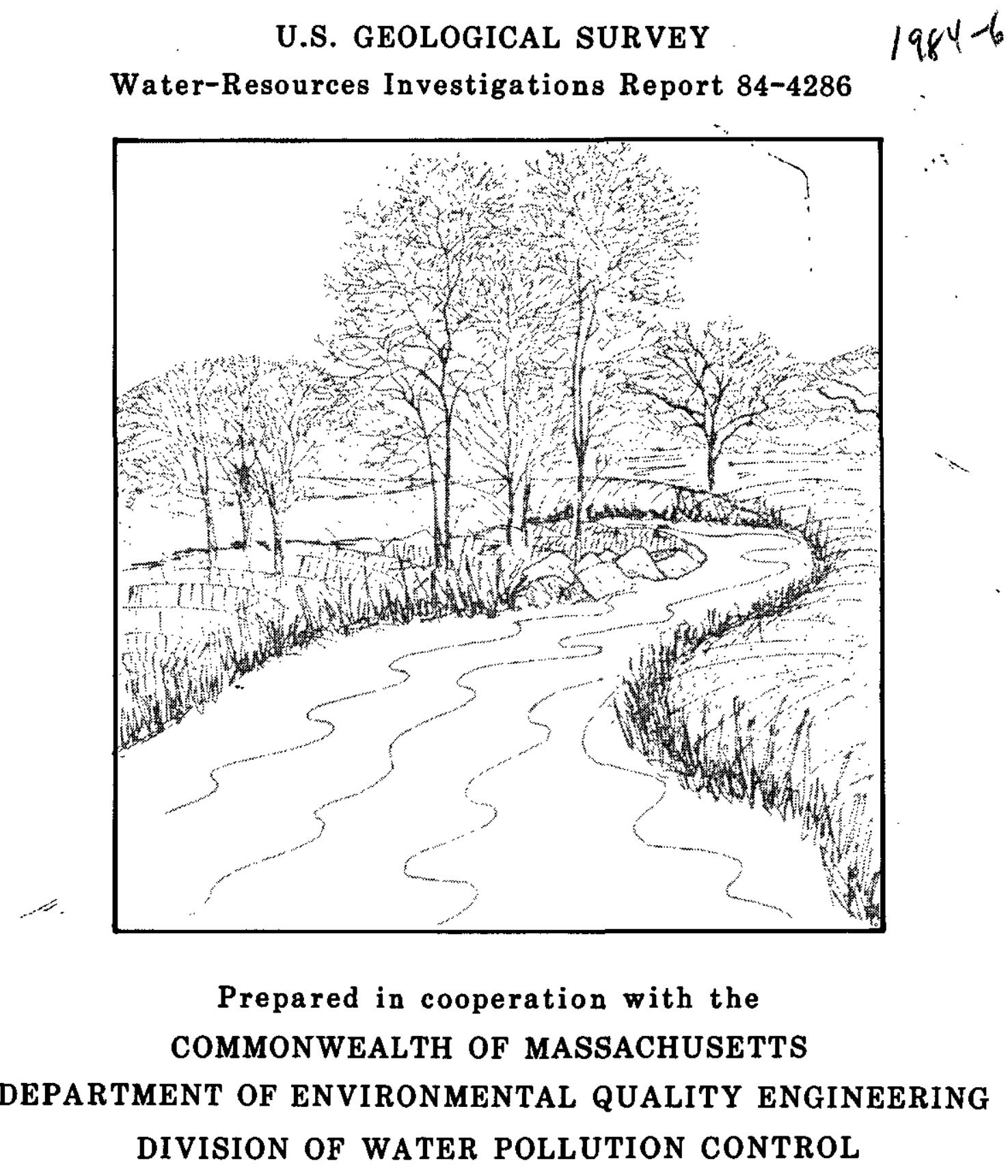




\title{
GAZETTEER OF HYDROLOGIC CHARACTERISTICS OF STREAMS IN MASSACHUSETTS--BLACKSTONE RIVER BASIN
}

\author{
By S.William Wandle, Jr., and Anita F. Phipps
}

U.S. GEOLOGICAL SURVEY

Water-Resources Investigations Report 84-4286

Prepared in cooperation with the

COMMONWEALTH OF MASSACHUSETTS

DEPARTMENT OF ENVIRONMENTAL QUALITY ENGINEERING

DIVISION OF WATER POLLUTION CONTROL

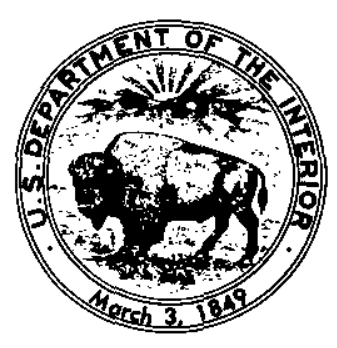

Boston, Massachusetts 1984 


\section{UNITED STATES DEPARTMENT OF THE INTERIOR}

WILLIAM P. CLARK, Secretary

GEOLOGICAL SURVEY

Dallas L. Peck, Director

For additional information write to:

U.S. Geological Survey

150 Causeway Street, Suite 1309

Boston, MA 02114
Copies of this report can be purchased from:

Open-File Services Section

Western Distribution Branch

U.S. Geological Survey

Box 25425, Federal Center

Denver, CO 80225

Telephone: (303) 236-7476 
Abstract-1.

Introduction-1

Hydrologic data-

Basin characteristics - 4

Streamflow characteristics

Streamflow analysis -

Streamflow data base-

Daily flow statistics

Low-flow statistics-_. 11

Summary -

Selected references -

\section{ILLUSTRATIONS}

Figures 1-2. Map showing location of the:

1. Blackstone River basin - 3

2. gaging stations and low-flow partial-record stations

in the Blackstone River basin-.. 5

3-5. Graphs showing:

3. monthly discharges and extremes for Quinsigamond River

at North Grafton, Mass. (site 10), during 1940-80- 8

4. flow-duration curve for the Blackstone River at

Nor thbridge, Mass. (site 11), during 1940-77 - 9

5. low-flow frequency curve for the Quinsigamond River

at North Grafton, Mass (site 10), during 1941-80 10

\section{TABLES}

Table 1. Stream-order listing, selected drainage areas, and locations

of subbasins in the Blackstone River basin

2. Summary of daily flow records and peak-flow records available

in the Blackstone River basin-

3. Basin characteristics for selected stream-gaging stations

4. Streamflow characteristics at selected stream-gaging stations $-\cdots$

5. Summary of 7-day low-flow characteristics, drainage area, and period of record for low-flow partial-record stations 


\section{CONVERSION FACTORS}

The following factors may be used to convert the inch-pound units published herein to the International System of Units (SI).

Multiply inch-pound units

inch (in)
foot (ft)
mile (mi)
square mile $\left(\mathrm{mi}^{2}\right)$
cubic foot per second ( $\left.\mathrm{ft}^{3} / \mathrm{s}\right)$
cubic foot $\mathrm{per}$ second per square
mile $\left[\left(\mathrm{ft}^{3} / \mathrm{s}\right) / \mathrm{mi}^{2}\right]$

foot per mile ( $\mathrm{ft} / \mathrm{mi}$ )
By

To obtain SI Units

\section{Length}

$25.4^{*}$

0.3048

1.609

Area

2.590

square kilometer $\left(\mathrm{km}^{2}\right)$

Flow

0.02832 cubic meter per second $\left(\mathrm{m}^{3} / \mathrm{s}\right)$

0.01093

cubic meter per second per square kilometer $\left[\left(\mathrm{m}^{3} / \mathrm{s}\right) / \mathrm{km}^{2}\right]$

Slope

$0.1894 \quad$ meter per kilometer $(\mathrm{m} / \mathrm{km})$

\section{Temperature}

Temperature in degrees Fahrenheit $\left({ }^{\circ} \mathrm{F}\right)$ can be converted to degrees Celsius $\left({ }^{\circ} \mathrm{C}\right)$ as follows:

$$
{ }^{\circ} \mathrm{C}=5 / 9\left({ }^{\circ} \mathrm{F}-32\right) \text {. }
$$




\title{
GAZETTEER OF HYDROLOGIC CHARACTERISTICS OF STREAMS
}

IN MASSACHUSETTS--BLACKSTONE RIVER BASIN

By S. William Wandle, Jr., and Anita F. Phipps

\begin{abstract}
The Blackstone River basin encompasses 335 square miles in south-central Massachusetts, including portions of Bristol, Middlesex, Norfolk, and Worcester Counties. Drainage areas, using the latest available 1:24,000 scale topographic maps, were computed for the first time for ungaged streams draining more than 3 square miles and were re-computed for data-collection sites.

Streamflow characteristics at six gaging stations were calculated using a new data base with daily flow records through 1980. These characteristics include annual and monthly flow statistics, duration of daily flow values, and the annual 7-day mean low flow at the 2-year and 10-year recurrence intervals. The 7-day, 10-year low-flow values are presented for 31 partial-record sites, and the procedures used to determine the hydrologic characteristics of the basin are summarized. Basin characteristics representing 14 commonly used indices to estimate various streamflows are presented for the six gaged streams. This gazetteer will aid in the planning and siting of water-resources related activities and will provide a common data base for governmental agencies and the engineering and planning communities.
\end{abstract}

\section{INTRODUCTION}

Information on hydrologic characteristics, including drainage areas, frequency of low flows, and duration of daily flows, is necessary to plan and manage water-resources related activities. Governmental agencies and the engineering and planning community need streamflow and basin characteristics to satisfy requirements relative to waste assimilation, fisheries management, hydropower, land-use planning, stream-systems analysis, and water-resource development and management. No current hydrologic data base containing a comprehensive list 
of drainage areas, monthly flows, low-flow frequencies, and duration of daily flows is available for most of the Massachusetts stream systems. Drainage areas are available for selected sites where streamflow data are collected. Streamflow characteristics are presented in various reports, but these data, to be current, need to be re-analyzed using the latest available daily flow records.

In response to this need, a study was begun in 1980, in cooperation with the Massachusetts Division of Water Pollution Control, to analyze available streamflow and river-basin characteristics, and to compute subbasin drainage areas. This report is one in a series of gazetteers on the hydrologic characteristics of the major river basins in the State. Gazetteers are also available for the coastal river basins of the North Shore and Massachusetts Bay (Wandle, 1984a), Connecticut River basin (Wandle, 1984b), Hudson River basin (Wandle, 1984c), Merrimack River basin (Wandle and Fontaine, 1984), Taunton and Ten Mile River basins (Wandle and Keezer, 1984), Housatonic River basin (Wandle and Lippert, 1984), Thames River basin (Wandle and LeBlanc, 1984), and coastal river basins of the South Shore and Buzzards Bay (Wandle and Morgan, 1984). This report provides the first detailed listing of drainage areas and streamflow characteristics derived from daily flow records in the Blackstone River basin. The streamflow characteristics presented are an expansion and an update of those given in Walker and Krejmas (1983).

The Blackstone River basin in south-central Massachusetts ( $\mathrm{fig} .1$ ) includes all or part of the following communities: Attleboro, Auburn, Bellingham, Blackstone, Boylston, Douglas, Franklin, Grafton, Holden, Hopedale, Hopkinton, Leicester, Mendon, Milford, Millbury, Millville, North Attleborough, Northbridge, Oxford, Paxton, Plainville, Shrewsbury, Sutton, Upton, Uxbridge, Webster, West Boylston, Westborough, Worcester, and Wrentham.

Streamflow characteristics presented for the five continuously gaged streams are based upon a new sample of daily flow records in comparison to flow records used in Higgins (1967), Knox and Soule (1949), and Male and Ogawa (1982). Streamflow records through the 1980 water year were available for this analysis. For each site, records were selected to represent a flow regime influenced by fairly constant river basin conditions (Wandle, 1983).

Drainage areas were computed for the first time for ungaged streams draining greater than $3 \mathrm{mi}^{2}$ and were re-computed for data-collection sites. Drainage divides, as delineated on the latest available 1:24,000 scale topographic quadrangle maps (Brackley and Wandle, 1982; Krejmas, 1982; and Wandle and Frimpter, 1982) were used to calculate drainage areas. Drainage areas for most of the long-term gaging stations in earlier reports were computed using the drainage divides as outlined on $1: 31,680$ or $1: 62,500$ scale topographic quadrangle maps.

Streamflow data used in this study are a part of the historic streamflow data collected under agreements with State and Federal agencies and the U.S. Geological Survey. Most of the low-flow discharge measurements used in determining low-flow estimates at partial-record sites were collected during the water-resources investigation of the Blackstone River basin (Walker and Krejmas, 1983). The file of basin characteristics was created during an evaluation of available streamflow data in central New England (Johnson, 1970). This file is an expansion of the characteristics abstracted by Langbein and others (1947), and by Benson (1962). Basin characteristics were updated and additional characteristics were entered as part of a study to define floodflow characteristics of small streams (Johnson and Tasker, 1974, and Wandle, 1982). The hierarchical stream list was compiled by the Massachusetts Division of Water Pollution Control and the Massachusetts Division of Fisheries and Wildlife (Halliwell and others, 1982).

Data tabulated include drainage areas, basin and streamflow characteristics for gaging stations, including annual and monthly flow statistics, duration of daily flow values, and the annual 7-day mean low flow at the 2-year and 10-year recurrence intervals. Estimates of the 7-day 10-year low flows for partial-record sites are also presented. An explanation of the procedures to determine the streamflow and basin characteristics is provided.

The authors thank the many persons who have kindly given time, information, and guidance during this study. Particular thanks are given to persons in the Geological Survey who assisted in the collection of the streamflow data, in the preparation of this report. 


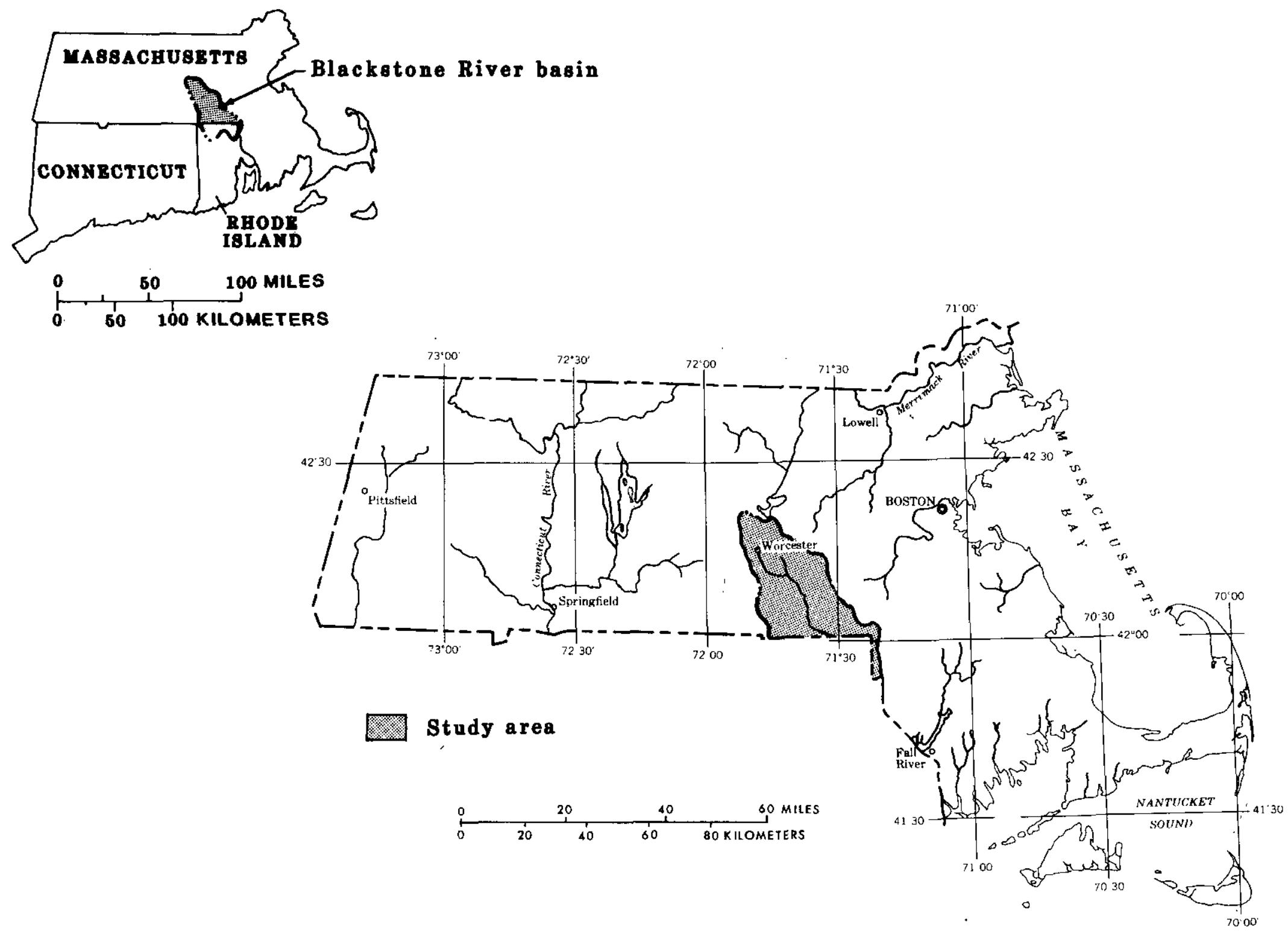

Figure 1.-Location of the Blackstone River basin 


\section{HYDROLOGIC DATA}

Hydrologic characteristics are represented by various physical, climatic, and streamflow indices of a river basin. These characteristics can be determined either from available maps by following standardized procedures or from historic streamflow records.

Basin characteristics are indices of the physiography of the basin or of the climate prevailing over the basin and are measured on topographic quadrangle or climatic maps. Streamflow characteristics are computed from continuous records of daily flow or from a set of measurements during the occurrence of a specific event. Streamflow and basin characteristics are used in modeling stream quality, assessing water-resources conditions, analyzing impact of man's activities, and defining relationships to estimate flows or stream-quality parameters at ungaged sites.

\section{Basin Characteristics}

Drainage area is one of the most important variables in any hydrologic investigation or in the design of riverine structures. Drainage area is the most significant variable in the northeast that influences all streamflow except perhaps low flow in some regions. The physical boundary for many water-related studies corresponds to the limits for the drainage area upstream from the site.

For this study, drainage areas listed in table 1 (at the end of the report) were determined for the following sites:

1. Survey data-collection sites shown in figure 2. These sites include continuous-record gaging stations given in table 2 (at the end of the report), low-flow partial-record stations, miscellaneous sites, and water-quality stations.

2. Locations where the drainage area is greater than $3 \mathrm{mi}^{2}$.

3. Successive sites along a stream where the area between sites is at least $6 \mathrm{mi}^{2}$ on tributary streams and $10 \mathrm{mi}^{2}$ on the Blackstone River.

The drainage basin divides for these sites were delineated on the latest available 1:24,000 scale topographic quadrangle maps. Subbasin drainage divides are shown in the series of statewide reports, "Drainage Divides, Massachusetts." The Blackstone River basin is covered by three reports in this series-Nashua and Concord River basins (Brackley and Wandle, 1982), Blackstone and Thames River basins (Krejmas, 1982), and Taunton River basin and southeast coastal basins (Wandle and Frimpter, 1982).

The subbasin drainage areas given in table 1 are indexed to the Massachusetts stream inventory prepared by the Massachusetts Division of Water Pollution Control and the Massachusetts Division of Fisheries and Wildlife (Halliwell and others, 1982) with some modification. Drainage areas were computed for sites meeting one of the three criteria mentioned above. The entire stream listing is included as a reference for stream order. This hierarchical listing begins at the mouth of a major stream and proceeds upstream with tributary streams indented under the main-stem stream. This order is followed to list all the named streams. Unnamed tributaries are included to maintain the hierarchy. The reader is referred to the inventory of rivers and streams report by Halliwell and others (1982) for a more detailed explanation.

The basin characteristics listed below are included because they represent indices that would remain reasonably stable over a planning period. They can be used in predictive models to assess impacts of proposed developments. The usefulness of these characteristics to explain the variability of various streamflow events has been demonstrated in hydrologic analyses (Thomas and Benson, 1970) and they can readily be measured from available maps. The 14 basin indices given in table 3 (at the end of the report) were computed according to the procedures described below. The indices for elevation, storage, lake area, and forest can be computed by the grid method which is explained after all the procedures are described. 


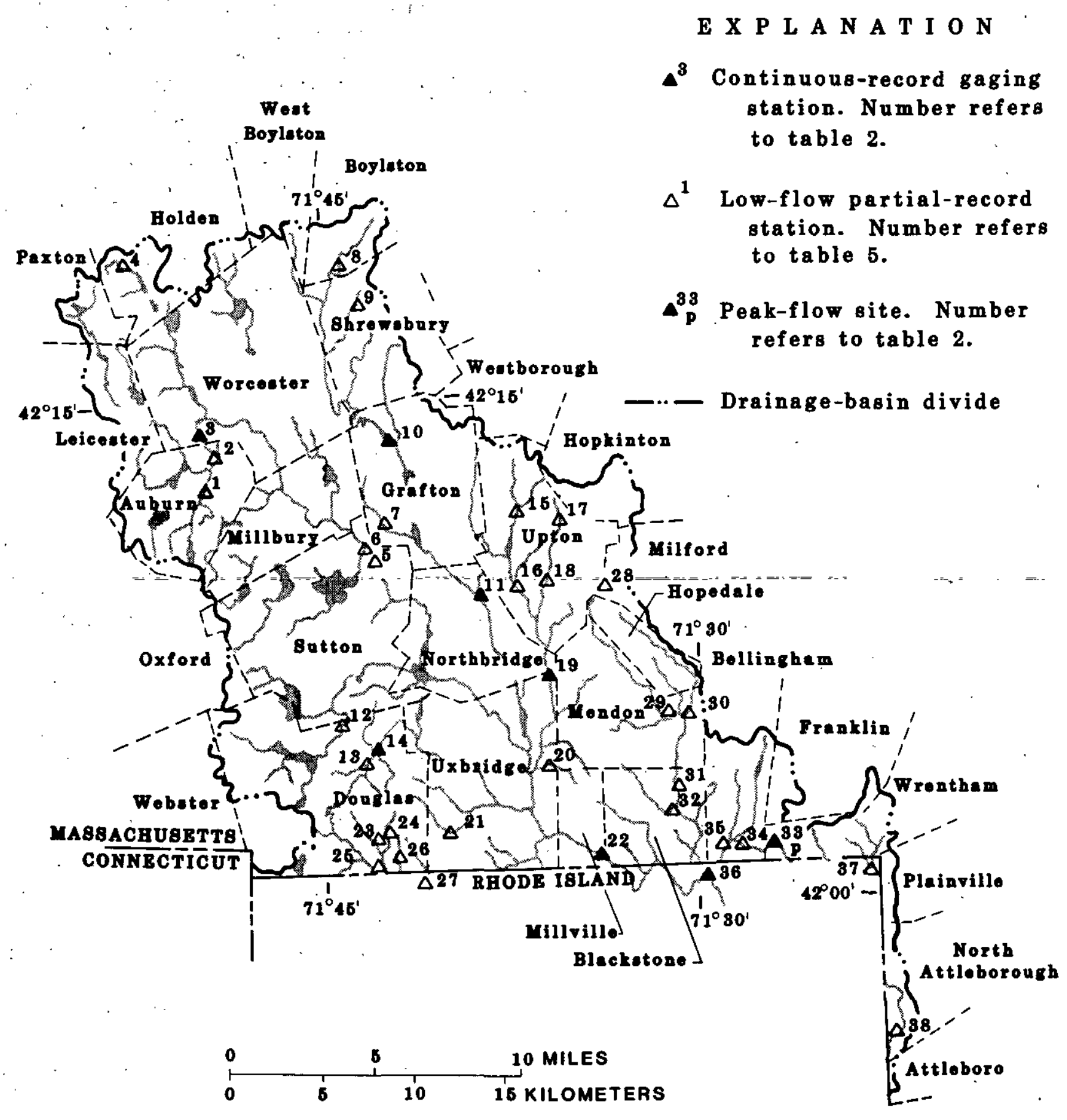

Figure 2.--Location of the gaging stations and low-flow partial-record stations in the Blackstone River basin 
1. Drainage area-Area, in square miles, as measured on the most recent $1: 24,000$ scale topographic quadrangle maps. Drainage area, as defined in the "National Handbook of Recommended Methods for Water-Data Acquisition" (U.S. Geological Survey, 1977), is "...the area of a river basin, measured in a horizontal plane, that is enclosed by a topographic divide such that direct surface runoff from precipitation normally would drain by gravity into the river basin.". Drainage area boundary lines are traced on topographic maps along divides indicated by contour elevations, starting at the point on the stream for which the drainage area is desired. These lines are drawn to cross a contour at right angles. Interpolation between contours may be indicated by reference to trails, old roads, or firebreaks in forested areas, all of which frequently follow drainage divides. Detailed information may also be obtained from highway or street profiles, from examination of aerial photographs, and from ground reconnaissance. Subareas within each quadrangle map were computed with an electronic digitizer using the procedures of the U.S. Federal Inter-Agency River Basin Committee (1951) as a guide. The coefficients to compute square miles from digitizer units were calculated using the known area of each 7.5-minute quadrangle or of the appropriate 2.5-minute quadrilaterals. Drainage areas for the subbasins were computed by summing the contributing areas.

2. Slope-Main-channel slope, in feet per mile, determined from elevations at points 10 percent and 85 percent of the distance along the main channel from the gaging station to the basin divide.

3. Length-Main-channel length, in miles, from the gaging station to the basin divide, as measured with dividers set to 0.1 mile or with a map measurer.

4. Elevation--Mean basin elevation, in feet above sea level, measured on topographic maps by laying a grid over the map.

5. Storage-Area of lakes, ponds, and marshes, in percent of total drainage area, measured by planimetering or by using a transparent grid. The marsh area includes the area of wooded marshes and marshes as defined by the appropriate topographic quadrangle map symbol. Storage area is the total area of all the lakes, ponds, and marshes expressed as a percentage of the total drainage area.

6. Lake area-Area of lakes and ponds, in percent of the drainage area, determined by the grid method.

7. Forest-Area of forest, in percentage of the drainage area, determined from the forest cover as shown on the topographic map with the green woodland overprint using the grid method.

8. Soil-Soil index, in inches, represents the value of potential maximum infiltration, during an annual flood, under average soil-moisture conditions. This characteristic, provided by the U.S. Soil Conservation Service (Dr. Benjamin Isgur, written commun., 1970), is a function of the soil and cover conditions in the basin. The index was computed from the runoff curve number following procedures in U.S. Department of Agriculture (1972).

9. Latitude-Latitude of stream-gaging station, in decimal degrees, determined by manual measurement.

10. Longitude-Longitude of stream-gaging station, in decimal degrees, determined by manual measurement.

11. Precipitation--Mean-annual precipitation, in inches, determined from the isohyetal map in Knox and Nordenson (1955). The variation in mean-annual precipitation is shown in more detail in this map than in more recent sources.

12. Precipitation intensity--Maximum 24-hour rainfall, in inches, having a recurrence interval of 2 years. This characteristic was determined from U.S. Weather Bureau (1959b).

13. Snowfall-Average total seasonal snowfall, in inches, from an isohyetal map in Lautzenheiser (1969).

14. January temperature-Minimum January temperature, in degrees Fahrenheit, determined from U.S. Weather Bureau (1959a). 
Several basin characteristies were measured following the grid method by using transparent grids to compute area or an average contour value. Storage area is determined by randomly placing the grid over the water and marsh area and counting squares. If the water and marsh area is large enough (about 30 squares), the number of grid intersections within the storage area are counted. The storage area then is computed as the product of the square size and the number of grid intersections. To measure a contour value such as elevation, the grid spacing is selected to give at least 25 intersections within the basin boundary. The elevation at each grid intersection is determined and an average is computed. The percentage of a variable that is extensive in a drainage basin, such as forest cover, can be easily measured by counting the number of grid intersections occurring over the forested area, multiplying by 100, and dividing by the number of grid intersections within the basin.

\section{Streamflow Characteristics}

Historic daily flow records available in the Blackstone River basin were used to compute daily, monthly, and annual flow characteristics. A summary of these records is given in table 2 and the location of streamflow sites is shown in figure 2. These flow data were collected as part of the Survey's nationwide data-collection network through agreements with State and Federal agencies. Records of daily flow are available from the Survey's National Water Data Storage and Retrieval System (WATSTORE). This water-data computer processing system consists of several files containing data grouped by common characteristic and data-collection frequency.

The WATSTORE system includes site identification, daily values files, and computer programs that produce streamflow statistics. Hydrologic-data files are maintained for (1) parameters measured on a daily or continuous basis, such as streamflow values, river stages, water temperatures, specific conductance values, and ground-water levels; (2) annual peak values for streamflow and stage; (3) ${ }^{-}$chemical ${ }^{-}$analyses ${ }^{-}$for surface $=$and ground-wäter sites; and (4) groundwater site inventory, including location, identification and geohydrologic characteristics. The data-processing, storage, retrieval, and analysis capabilities of WATSTORE are described in the system user's guide compiled by Hutchison (1975). Information regarding the availability of data analyses may be obtained from: U.S. Geological Survey, 150 Causeway Street, Suite 1309, Boston, MA 02114.

A brief description of the streamflow statistics computed using the WATSTORE system is included below. Streamflow characteristics representing annual, monthly, and daily flow statistics were selected for this analysis because they are useful in planning and design studies in this region. The streamflow statistics computed following the procedures given below are listed in table 4 (at the end of the report).

Annual and monthly flow characteristics (means and standard deviations) were computed at six gaging stations with the "Daily Values Monthly and Annual Statistics" computer program W4422 (Price and Meeks, 1977) using observed daily flow records. The maximum and minimum, monthly means (fig. 3 and table 4) were obtained from output provided by this program. The monthly hydrograph for Quinsigamond River at Grafton is shown in figure 3.

Characteristics of the flow-duration curve (the daily flow exceeded 99, 95, 90, 75, 70, 50, 25 , and 10 percent of the time) for six gaging stations were computed by means of computer program A969, "Daily Values Statistics" (Meeks, 1977). An example of a flow-duration curve for the Blackstone River at. Northbridge is given in figure 4. Low-flow characteristics (annual 7-day mean low flows at the 2-year and 10-year recurrence intervals 7Q2 and 7Q10, respectively) at five gaging stations were also calculated by program A969. In this program, a $\log$-Pearson Type III distribution is fitted to a set of observed annual 7-day mean low flows to obtain coordinates of the computed low-flow frequency curve. If the log-Pearson Type III curve did not adequately fit a plot of the observed data, especially in the low end, then a graphical curve was drawn. The graphical frequency curve was used to interpret the observed data when necessary because a graphical curve is the basic curve to use in analyzing the frequency of annual low flows according to Riggs $(1971,1972)$. The frequency curve for the Quinsigamond River at North Grafton is shown in figure 5.

Additional flow data, including flood-frequency analyses, are available from WATSTORE. Peak discharges for selected recurrence intervals for 82 sites in Massachusetts are given in Wandle (1982). 


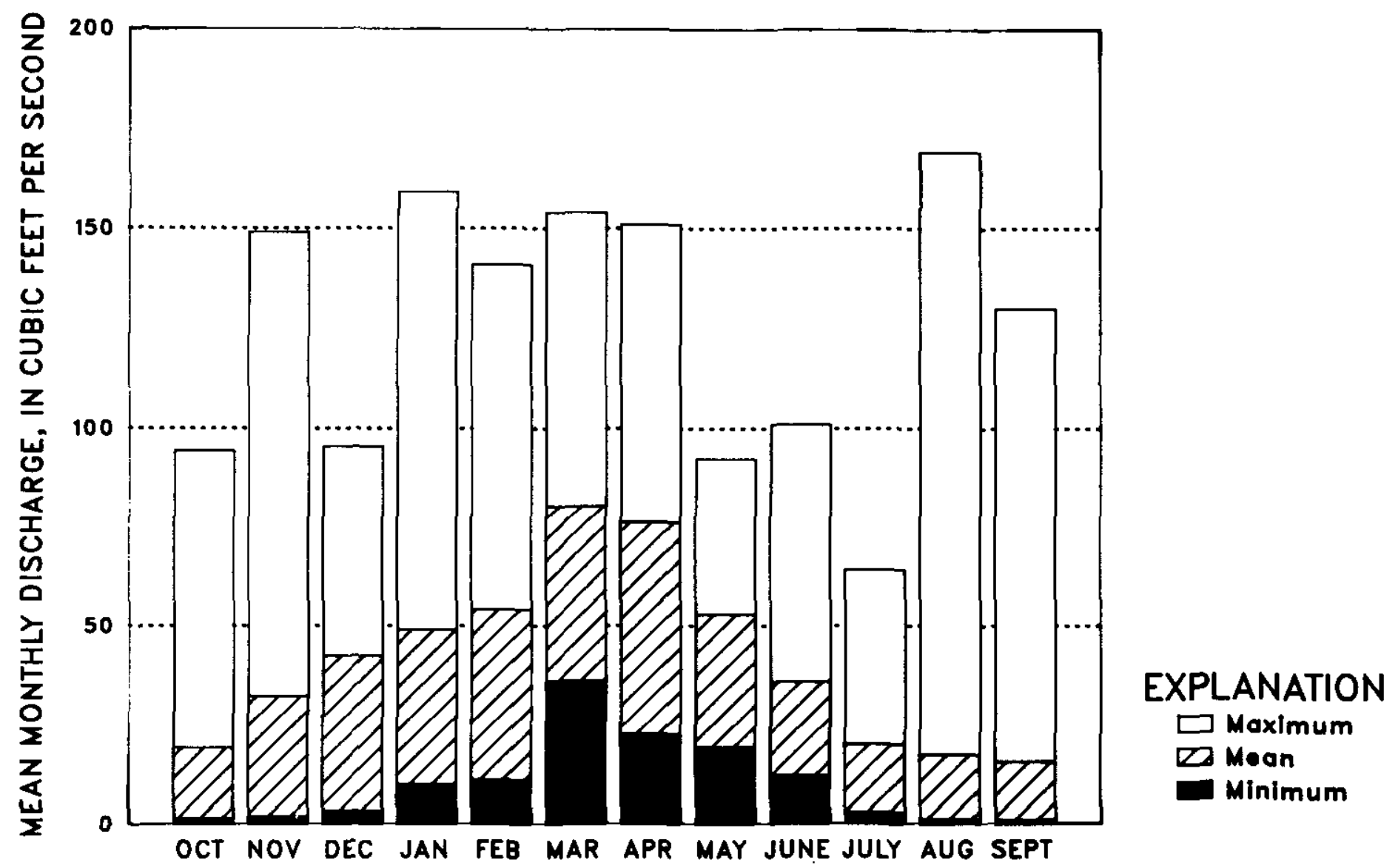

Figure 3.--Monthly discharges and extremes for Quinsigamond River at North Grafton, Mass. (site 10), during 1940-80 


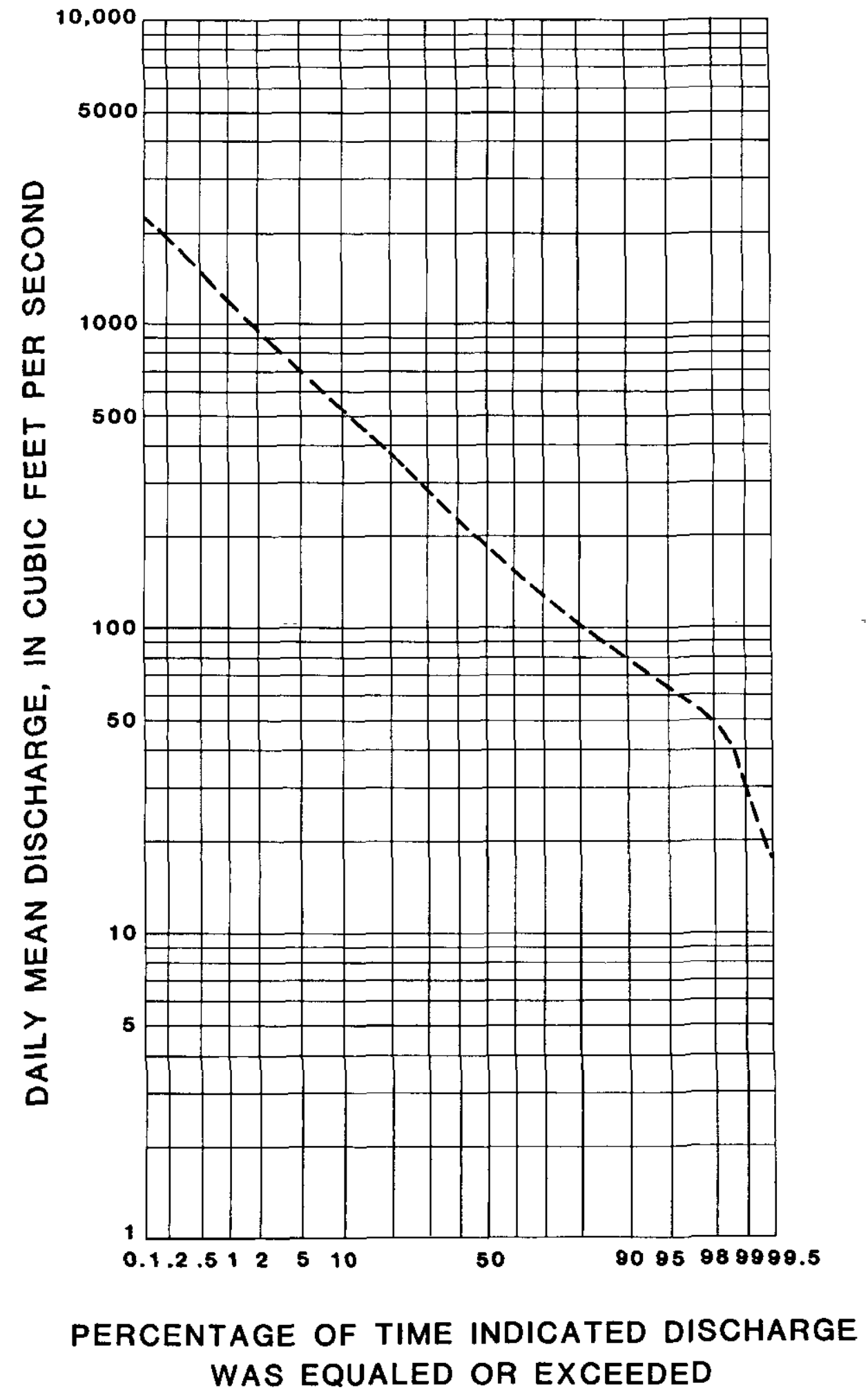

Figure 4.--Flow-duration curve for the Blackstone River at Northbridge, Mass. (site 11), during 1940-77 


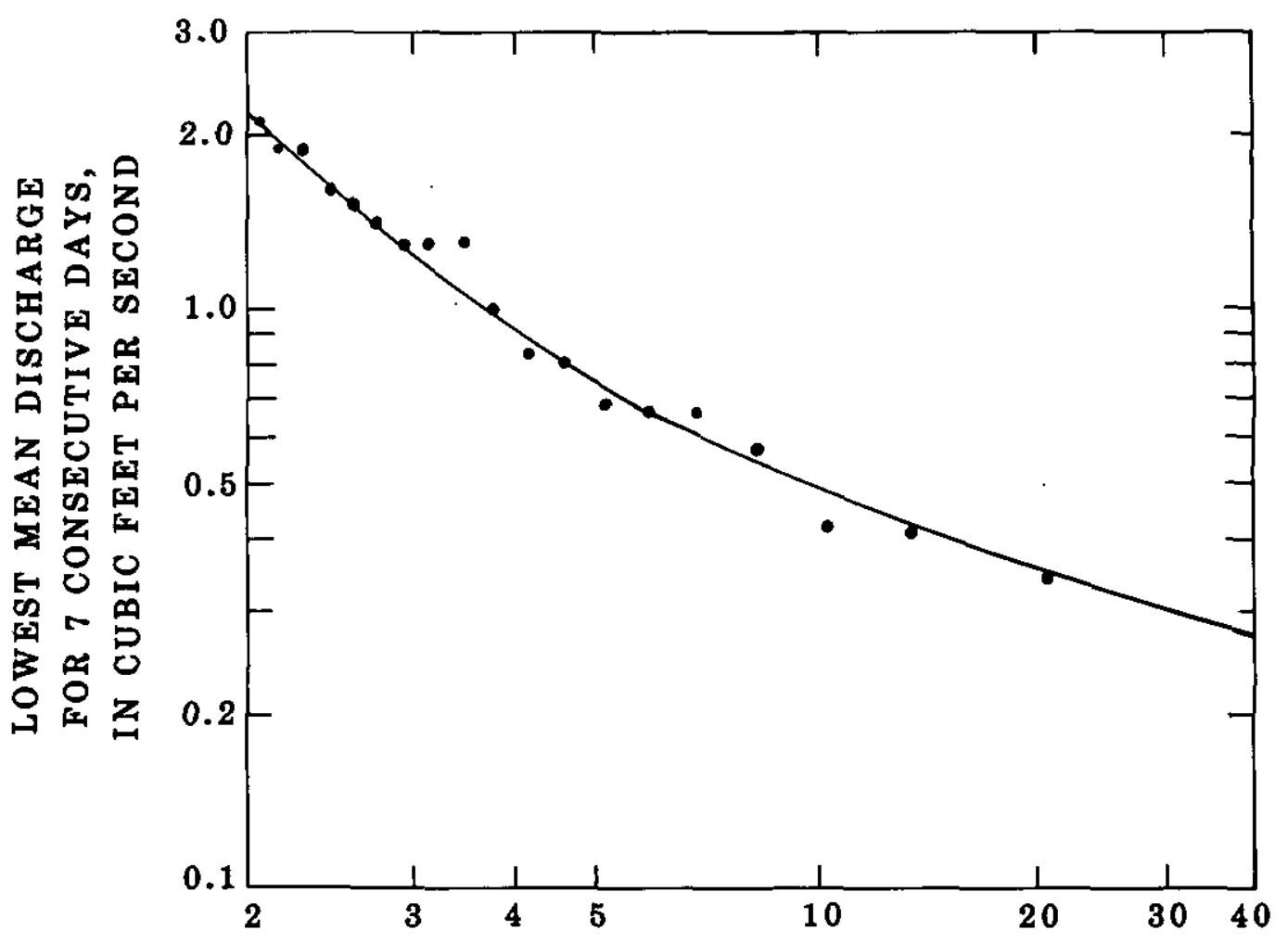

RECURRENCE INTERVAL, IN YEARS

Figure 5.--Low-flow frequency curve for the Quinsigamond River at North Grafton, Mass, (site 10), during 1941-80

Characteristics of low flow were also determined at low-flow partial-record stations where measurements of discharge, rather than a continuous daily flow record, were available. This estimating technique is briefly described in the section on Streamflow Analysis. The 7-day low-flow statistics were developed from discharge measurements made during periods of base runoff. Base runoff is defined (Langbein and Iseri, 1960) as "the sustained or fair weather runoff. In most streams, base flow is composed largely of ground-water effluent." Base runoff usually occurs in most Massachuset ts streams during the summer months or early fall after 5 to 7 consecutive days without rainfall.

\section{STREAMFLOW ANALYSIS}

\section{Streamflow Data Base}

Systematic records of daily streamflow have been collected since at least 1924 in the Blackstone River basin. The location and period of record for these gaging stations are given in table 2. Streamflow records are available for other sites in the Rhode Island portion of the basin from the U.S. Geological Survey office in Boston, Massachusetts.

Discharge measurements were made at 25 low-flow partial-record sites during the waterresources investigation of the Blackstone River basin (Walker and Krejmas, 1983). Measurements were also collected as part of the Massachusetts low-flow network at one site in 1978 and at one site during 1965. Data were collected on Massachusetts streams as part of the Rhode Island water-resources program in two tributary basins of the Blackstone River basin. Discharge measurements were made at four sites in the Branch River basin (Johnston and Dickerman, 1974b) and at site in the Abbott Run basin (Johnston and Dickerman, 1974a). 
Flow characteristics are useful in resource management and design studies if these variables represent a particular regulated flow sequence or the natural flow regime that is expected to occur in the future. A valid streamflow analysis is based upon flow records during a period of relatively constant river-basin conditions.

\section{Daily Flow Statistics}

Systematic daily flow records available for six sites in the Blackstone River basin were reviewed to select a data base for statistical analysis. Impacts of reservoirs, diversions, regulation, and withdrawals for public supplies on streamflows were assessed using information on stream regulation found in the series of water-resources data reports issued annually (see U.S. Geological Survey, 1980, for an example) and in Knox and Soule (1949). Streamflow records for six sites were selected that represent a flow regime influenced by fairly constant river-basin conditions (Wandle, 1983). The record length used in this analysis is given in table 4. Low flow, monthly flow, and flow-duration characteristics given in table 4 were derived from the observed streamflow records at each station and are not adjusted for regulation or diversion. These daily streamflow characteristics were computed following procedures summarized in the section on streamflow characteristics.

\section{Low-Flow Statistics}

Continuous streamflow records are not necessary to estimate low-flow characteristics at sites. According to Riggs (1972) selected base-flow measurements rather than a continuous daily flow record can define the low-flow characteristics at a site.

Low-flow partial-record stations are operated to collect discharge measurements when streamflow is composed largely of ground-water runoff. These low-flow sites are selected on streams where flow is expected to occur during a significant dry spell and where the flow is not affected by artifical regulation. Base-flow measurements to define a relation with concurrent gaged flows are obtained over several low-flow periods.

A relation is developed with the base-flow measurements and the concurrent daily mean flows at a nearby long-record gaging station (index station). The 7-day low-flow statistics (7Q2 and $7 Q 10$ ) for the site are determined from this relation using the appropriate low-flow statisties for the gaged stream. This estimating technique is explained in more detail by Riggs (1972).

The 7-day 10-year low-flow statistics for 31 sites in the Blackstone River basin are summarized in table 5 (at the end of the report). These low-flow statistics are representative of the hydrologic regime during the data-collection period. Seven-day 10-year low-flow statistics range from 0 to $0.14\left(\mathrm{ft}^{3} / \mathrm{s}\right) / \mathrm{mi}^{2}$. Branch River at Forestdale and Nipmuc River near Harrisville, both in Rhode Island, and Sevenmile River near Spencer and Squannacook River near West Groton were used as the index stations. These values were computed following the procedures mentioned above.

\section{SUMMARY}

Drainage areas were computed for the first time for ungaged streams draining greater than $3 \mathrm{mi}^{2}$ and were re-computed for data-collection sites. Basin characteristics for drainage area, slope, length, elevation, lake area, soil, latitude, longitude, precipitation, precipitation intensity, snowfall, and January minimum temperature are provided for the five gaged sites in the Blackstone River basin. Computer programs A969 and W4422 were used to determine daily flow statistics including annual and monthly flows, duration of daily flows, and 7-day low-flow values. Seven-day 10-year low flows ranged from 0 to $0.14\left(\mathrm{ft}^{3} / \mathrm{s}\right) / \mathrm{mi}^{2}$ at the 31 partialrecord stations.

Techniques used to compute basin and streamflow characteristics of a river basin are summarized. This gazetteer contains a comprehensive listing of hydrologic characteristics that should prove useful to those concerned with water-resources activities. 
Table 1.-Stream-order listing, selected drainage areas, and locations of subbasins within the Blackstone River basin

[Sites with streamflow information listed in tables 2, 4, or 5 are marked with an asterisk. The hierarchical listing is modified from Halliwell and others, 1982. Drainage areas are shown for sites as explained in the section on basin characteristics. These areas are not adjusted for manmade changes in the flow system. Streams entirely in adjacent states are underlined and are included in the list where necessary to maintain the stream order.]

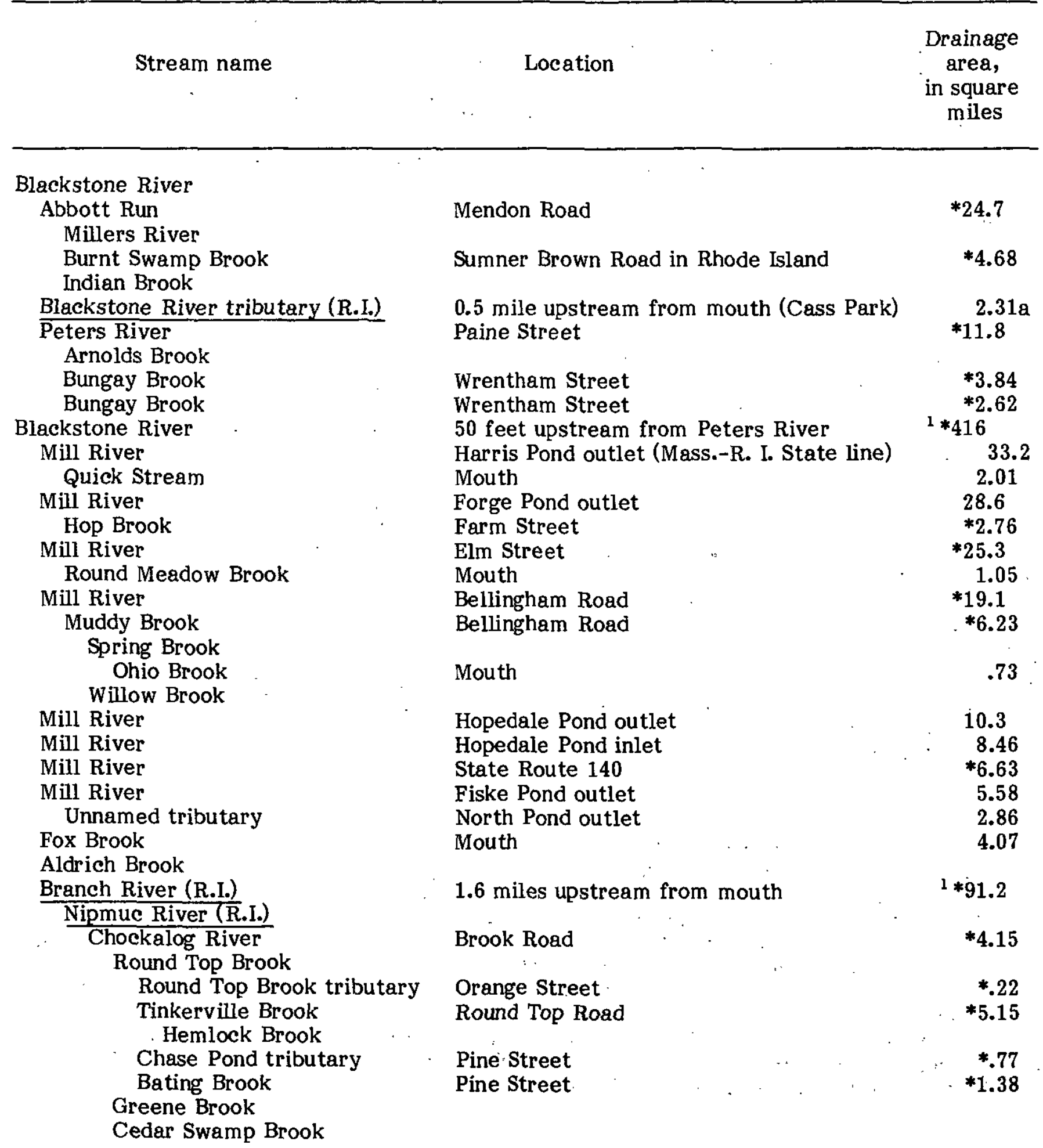


Table 1.-Stream-order listing, selected drainage areas, and locations of subbasins within the Blackstone River basin (Continued)

Stream name

Location

Drainage area,

in square

miles

Blackstone River

Blackstone River

Bacon Brook

Card Machine Brook

Unnamed tributary

Aldrich Brook

Emerson Brook

Happy Hollow Brook

Unnamed tributary

Unnamed tributary

Scadden Brook

Unamed Brook

West River

Laurel Brook

Still Corner Brook

Meadow Brook

Wigwam Brook

Rock Meadow Brook

West River

Taft Pond Brook

Taft Pond Brook Miscoe Brook

Center Brook

Center Brook

Center Brook

Center Brook

West River

West River

Warren Brook

Unnamed tributary Miscoe Brook

Mumford River

Unnamed tributary Cold Spring Brook

Farrel Brook

Unnamed tributary

Purgatory Brook

Cook Allen Brook

Steamburg Brook

Mumford River

Dunleavey Brook

Gilboa Brook

Wellman Brook

Mumford River

Unnamed Brook

Unnamed Brook

Southwick Brook
Dam 300 feet upstream from

Mass.-R. I. State line

400 feet upstream from railroad bridge

*263

Mouth

Mouth

Laurel Street

Blackstone Street

*1.28

Mouth

Mouth

3.12

250 feet downstream from West Hill Dam

$* 27.8$

Upstream from Miscoe Brook

.69

Taft Pond outlet

1.00

Mouth

7.37

Mendon Street

*6.03

Unamed pond outlet

4.24

Hopkinton Road

*2.10

Upstream from Center Brook

15.6

Pleasant Street

Fowler Street

$* 14.7$

*3.81

Stowe Road

4.49

Mouth

56.6

State Route 122

$\mathbf{3 . 5 7}$

50 feet downstream from Lackey Dam

34.4

100 feet upstream from Manchaug Road

$* 29.1$ 
Table 1.--Stream-order listing, selected drainage areas, and locations of subbasins within the Blackstone River basin (Continued)

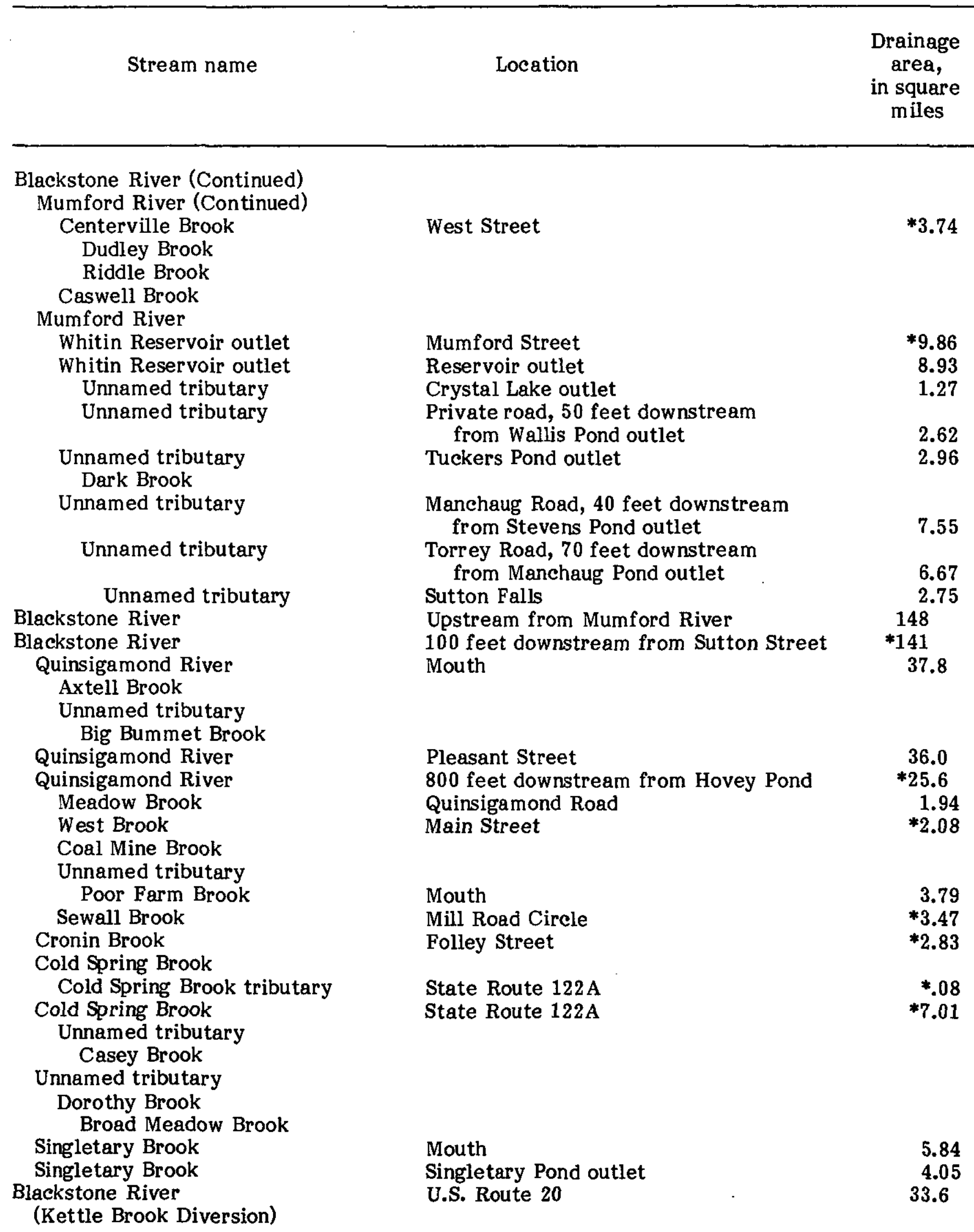


Table 1.-Stream-order listing, selected drainage areas, and locations of subbasins within the Blackstone River basin (Continued)

\begin{tabular}{|c|c|c|}
\hline Stream name & Location & $\begin{array}{l}\text { Drainage } \\
\text { area, } \\
\text { in square } \\
\text { miles }\end{array}$ \\
\hline \multicolumn{3}{|l|}{ Blackstone River (Continued) } \\
\hline \multicolumn{3}{|l|}{ Middle River } \\
\hline Unnamed tributary & & \\
\hline $\begin{array}{l}\text { Kettle Brook } \\
\text { (Kettle Brook Diversion) }\end{array}$ & 75 feet downstream from Webster Street & $\begin{array}{c}* 31.6 \\
*--\end{array}$ \\
\hline $\begin{array}{l}\text { Ramshorn Brook } \\
\text { Dark Brook }\end{array}$ & State Route 12 & $* 11.1$ \\
\hline $\begin{array}{l}\text { Ramshorn Brook } \\
\text { Stone Brook }\end{array}$ & U.S. Route 20 & 7.44 \\
\hline Ramshorn Brook & Cartelon Road & 4.19 \\
\hline Dark Brook & Dark Brook Reservoir outlet & 2.67 \\
\hline $\begin{array}{l}\text { Unnamed tributary } \\
\text { Chapin Brook } \\
\text { Kinnear Brook } \\
\text { Lynde Brook }\end{array}$ & & \\
\hline $\begin{array}{l}\text { Kettle Brook } \\
\text { Beaver Brook } \\
\text { Weasel Brook }\end{array}$ & Kettle Brook Reservoir No. 1 outlet & 4.18 \\
\hline Unnamed tributary & Coes Reservoir outlet & 11.4 \\
\hline $\begin{array}{c}\text { Tatnuck Brook } \\
\text { The Cascade }\end{array}$ & Mower Street & 7.48 \\
\hline $\begin{array}{l}\text { Tatnuck Brook } \\
\text { Silver Spring Brook }\end{array}$ & Holden Reservoir No. 2 outlet & 5.23 \\
\hline $\begin{array}{l}\text { Scott Brook } \\
\text { Wadsworth Brook }\end{array}$ & South Road & $* 1.14$ \\
\hline
\end{tabular}

${ }^{1}$ U.S. Geological Survey, 1980.

a Drainage basin is outside of Massachusetts. 
Table 2.-Summary of daily flow records and peak-flow records available in the Blackstone River basin

\begin{tabular}{|c|c|c|c|c|c|}
\hline $\begin{array}{l}\text { Number } \\
\text { in } \\
\text { figure } 2\end{array}$ & $\begin{array}{l}\text { Station } \\
\text { number }\end{array}$ & Station name & Location & $\begin{array}{l}\text { Period } \\
\text { of } \\
\text { record }\end{array}$ & Remarks \\
\hline 2 & 01109480 & $\begin{array}{l}\text { Kettle Brook Diversion } \\
\text { Weir at Auburn, Mass. }\end{array}$ & Diversion weir & $1979-80$ & (1) \\
\hline 3 & 01109500 & $\begin{array}{l}\text { Kettle Brook at } \\
\text { Worcester, Mass. }\end{array}$ & $\begin{array}{l}75 \text { feet downstream } \\
\text { from Webster Street }\end{array}$ & $1924-80$ & (2) \\
\hline 10 & 01110000 & $\begin{array}{l}\text { Quinsigamond River at } \\
\text { North Grafton, Mass. }\end{array}$ & $\begin{array}{l}800 \text { feet downstream } \\
\text { from Hovey Pond }\end{array}$ & $1940-80$ & (3) \\
\hline 11 & 01110500 & $\begin{array}{c}\text { Blackstone River at } \\
\text { Northbridge, Mass. }\end{array}$ & $\begin{array}{l}100 \text { feet downstream } \\
\text { from Sutton Street }\end{array}$ & $1940-80$ & (4) \\
\hline 14 & 01111000 & $\begin{array}{l}\text { Mumford River at } \\
\text { East Douglas, Mass. }\end{array}$ & $\begin{array}{l}100 \text { feet upstream } \\
\text { from Manchaug Road }\end{array}$ & $1940-51$ & (s) \\
\hline 19 & 01111200 & $\begin{array}{l}\text { West River below } \\
\text { West Hill Dam } \\
\text { near Uxbridge, Mass. }\end{array}$ & $\begin{array}{l}250 \text { feet downstream } \\
\text { from West Hill Dam }\end{array}$ & $1963-80$ & (6) \\
\hline 22 & 01111230 & $\begin{array}{l}\text { Blackstone River } \\
\text { at Millville, Mass. }\end{array}$ & $\begin{array}{l}400 \text { feet upstream } \\
\text { from railroad bridge }\end{array}$ & $1970-80$ & (7) \\
\hline 33 & 01112300 & $\begin{array}{l}\text { Bungay Brook near } \\
\text { Sheldonville, Mass. }\end{array}$ & Wrentham Street & $1964-74$ & (8) \\
\hline-- & 01111500 & $\begin{array}{l}\text { Branch River at } \\
\text { Forestdale, R.I. }\end{array}$ & $\begin{array}{l}1.6 \text { miles upstream } \\
\text { from mouth }\end{array}$ & $1941-80$ & (9) \\
\hline 36 & 01112500 & $\begin{array}{l}\text { Blackstone River at } \\
\text { Woonsocket, R.I. }\end{array}$ & $\begin{array}{l}50 \text { feet upstream } \\
\text { from Peters River }\end{array}$ & $1930-80$ & $(10)$ \\
\hline
\end{tabular}

${ }^{1}$ Annual maximum flow through diversion tunnel. Diversions since 1959, usually during periods of high flow.

${ }^{2}$ Regulated by reservoirs. Regulation at low flow probably greater prior to 1938. Diversions for municipal use and through diversion tunnel. Record includes flow through tunnel prior to 1977. Daily record discontinued. Peak-flow site since 1978.

${ }^{3}$ Regulated by Lake Quinsigamond and by ponds.

${ }^{4}$ Regulated by mills and reservoirs. Regulation at low flow probably greater prior to 1952 . Discharge includes diversions from Nashua River basin and Quabbin Reservoir at times since 1966. Miscellaneous measurement site since 1978.

${ }_{6}^{5}$ Regulated by mills and by ponds. Discontinued.

${ }^{6}$ Regulated by West Hill Dam.

${ }^{7}$ Water-quality monitor.

${ }^{8}$ Peak-flow site. Discontinued.

${ }^{9}$ Regulated by mills and reservoirs prior to 1957 .

${ }^{10}$ Regulated by powerplants, by West Hill Reservoir since 1961, and by other reservoirs. Discharge includes diversions from Nashua River basin and from Quabbin Reservoir at times since 1966, and flow diverted around station in Hamlet Trench prior to 1964. 
Basin characteristics

Station number and site number

\begin{tabular}{|c|c|c|c|c|c|}
\hline & Quinsigamond & & Mumford & Bungay & Blackstone \\
\hline Brook & $\begin{array}{l}\text { River at } \\
\text { North }\end{array}$ & $\begin{array}{c}\text { Blackstone } \\
\text { River at }\end{array}$ & $\begin{array}{l}\text { River at } \\
\text { East }\end{array}$ & $\begin{array}{l}\text { Brook } \\
\text { near }\end{array}$ & $\begin{array}{l}\text { River at } \\
\text { East }\end{array}$ \\
\hline
\end{tabular}

Worcester, Grafton, Northbridge, Douglas, Sheldon- Woonsocket, Mass. Mass. Mass. Mass. ville, Mass. R. I.

(10)

(11)

(14)

(33)

(36)

\begin{tabular}{|c|c|c|c|c|c|c|}
\hline Area, in square miles & 31.6 & 25.6 & 141 & 29.1 & 2.62 & ${ }^{1} 416$ \\
\hline Slope, in feet per mile & -- & 18.6 & 24.8 & 32.0 & 36.3 & 11.5 \\
\hline Length, in miles & - & 10.2 & 23.4 & 7.8 & 2.6 & 42.6 \\
\hline Elevation, in feet & - & 496 & 611 & 637 & 330 & 500 \\
\hline Storage, in percent & - & - & - & - & 22.7 & - \\
\hline Lake area, in percent & - & 5.8 & 4.2 & 5.2 & 1.5 & 3.0 \\
\hline Forest, in percent & - & - & - & - & 65 & 67 \\
\hline Soils index, in inches & - & 5.24 & 4.44 & 5.29 & 5.9 & 5.5 \\
\hline $\begin{array}{l}\text { Latitude of gage, } \\
\text { in decimal degrees }\end{array}$ & 42.2319 & 42.2303 & 42.1536 & 42.0733 & 42.0247 & 42.0061 \\
\hline $\begin{array}{l}\text { Longitude of gage, } \\
\text { in decimal degrees }\end{array}$ & 71.8353 & 71.7114 & 71.6525 & 71.7161 & 71.4567 & 71.5036 \\
\hline Precipitation, in inches & - & 44.0 & 44.0 & 44.0 & 45.0 & 44.2 \\
\hline $\begin{array}{l}\text { Precipitation intensity } \\
\text { for 2-year recurrence } \\
\text { interval, in inches }\end{array}$ & - & 3.2 & 3.3 & 3.5 & 3.5 & 3.4 \\
\hline Snowfall, in inches & - & 53 & 55 & 52 & 50 & 52 \\
\hline $\begin{array}{l}\text { January minimum } \\
\text { temperature, in } \\
\text { degrees Fahrenheit }\end{array}$ & - & 18 & 17 & 18 & 18 & 17 \\
\hline
\end{tabular}

${ }^{1}$ U.S. Geological Survey, 1980 
Table 4.--Streamflow characteristics, in cubic feet per second, at selected stream-gaging stations

Annual and monthly flow characteristics:

QA is the mean annual discharge

SDQA is the standard deviation of mean annual discharge

$\mathrm{QM}$ is the mean discharge for $\mathrm{M}$ calendar month, $\mathrm{M}=1$ for January where the top line is the maximum mean; the middle line is the mean; the bottom line is the minimum mean

SDQM is the standard deviation of mean discharge for $M$ calendar month

Low-flow characteristics:

7Q2 is the annual minimum 7-day mean discharge for 2-year recurrence interval

$7 Q 10$ is the annual minimum 7-day mean discharge for 10 -year recurrence interval

Flow-duration characteristics:

DPT is the daily discharge, exceeded PT percent of the time, from the flow-duration curve

Years of record:

YRSDAY is the number of years of daily flow record for this analysis

YRSLOW is the number of years of low-flow record for this analysis

Flow

Station name and site number

$\begin{array}{cccccc}\text { Kettle } & \text { Quinsigamond } & & \text { Mumford } & \text { West River } & \text { Blackstone } \\ \text { Brook } & \text { River at } & \text { Blackstone } & \text { River at } & \text { below West } & \text { River at } \\ \text { at } & \text { North } & \text { River at } & \text { East } & \text { Hill Dam near } & \text { East } \\ \text { Worcester, } & \text { Grafton, } & \text { Northbridge, } & \text { Douglas, } & \text { Uxbridge, } & \text { Woonsocket, } \\ \text { Mass. } & \text { Mass. } & \text { Mass. } & \text { Mass. } & \text { Mass. } & \text { R. I. } \\ (3) & (10) & (11) & (14) & (19) & (36)\end{array}$

ANNUAL

QA

45.2

41.2

266

44.8

45.9

758

SDQA

15.4

12.2

72.9

10.5

13.6

204

\section{MONTHLY}

Q10

170

24.3

3.89

94.3

19.1

1.22

438

157

56.4

39.3

27.1

17.0

53.9

2007

16.7

SDQ10

25.2

19.4

128

6.53

16.1

336

Q11

153

149

522

224

7.13

32.1

44.5

104

31.6

35.2

2233

15.3

3.30

624

127

SDQ11

31.2

28.2

157

9.75

32.1

474

Q12

128

95.4

603

42.3

266

.77

3.07

86.9

75.2

39.5

16.6

136

53.0

2265

821

23.3

139

18.6

36.7

504 
Table 4.--Streamflow characteristics, in cubic feet per second, at selected stream-gaging stations.(Continued)

Flow

Station name and site number

Kettle Quinsigamond

Brook River at

at

Mass.

(3)
North

Grafton,

Mass.

(10)

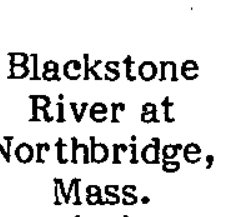

(11)
Mumford

River at

East

Douglas,

Mass.

(14)
West River

below West

Hill Dam near

Uxbridge,

Mass.

(19)
Blackstone

River at

East

Woonsocket,

R. 1 .

(36)

MONTHLY (Continued)

\begin{tabular}{|c|c|c|c|c|c|c|}
\hline Q1 & $\begin{array}{r}115 \\
49.3 \\
9.73\end{array}$ & $\begin{array}{r}159 \\
49.0 \\
9.85\end{array}$ & $\begin{array}{c}549 \\
282 \\
93.8\end{array}$ & $\begin{array}{c}84.1 \\
49.5 \\
9.27\end{array}$ & $\begin{array}{r}148 \\
59.9 \\
7.86\end{array}$ & $\begin{array}{r}3167 \\
961 \\
203\end{array}$ \\
\hline SDQ1 & 27.7 & 29.8 & 128 & 23.2 & 39.5 & 553 \\
\hline Q2 & $\begin{array}{l}109 \\
51.0 \\
20.8\end{array}$ & $\begin{array}{l}141 \\
54.1 \\
11.0\end{array}$ & $\begin{array}{l}832 \\
324 \\
153\end{array}$ & $\begin{array}{c}137 \\
60.1 \\
15.3\end{array}$ & $\begin{array}{l}159 \\
70.0 \\
13.4\end{array}$ & $\begin{array}{r}2493 \\
958 \\
262\end{array}$ \\
\hline SDQ2 & 23.2 & 25.8 & 141 & 30.4 & 45.7 . & 425 \\
\hline Q3 & $\begin{array}{l}303 \\
94.7 \\
35.9\end{array}$ & $\begin{array}{r}154 \\
80.6 \\
35.9\end{array}$ & $\begin{array}{r}1072 \\
515 \\
250\end{array}$ & $\begin{array}{c}139 \\
80.2 \\
33.0\end{array}$ & $\begin{array}{l}206 \\
105 \\
70.5\end{array}$ & $\begin{array}{r}4063 \\
1537 \\
740\end{array}$ \\
\hline $\mathrm{SDQ}^{3}$ & 46.7 & 25.0 & 172 & 30.8 & 35.2 & 598 \\
\hline Q4 & $\begin{array}{l}222 \\
89.7 \\
21.4\end{array}$ & $\begin{array}{c}151 \\
76.3 \\
22.5\end{array}$ & $\begin{array}{l}923 \\
475 \\
192\end{array}$ & $\begin{array}{c}110 \\
65.8 \\
41.5\end{array}$ & $\begin{array}{c}180 \\
95.8 \\
33.3\end{array}$ & $\begin{array}{r}2520 \\
1404 \\
479\end{array}$ \\
\hline SDQ4 & 46.5 & 30.1 & 201 & 20.0 & 33.9 & 534 \\
\hline Q5 & $\begin{array}{c}106 \\
51.1 \\
16.3\end{array}$ & $\begin{array}{l}92.3 \\
52.9 \\
19.2\end{array}$ & $\begin{array}{l}608 \\
303 \\
123\end{array}$ & $\begin{array}{l}99.1 \\
62.4 \\
31.5\end{array}$ & $\begin{array}{c}118 \\
54.5 \\
24.3\end{array}$ & $\begin{array}{r}1179 \\
873 \\
303\end{array}$ \\
\hline SDQ5 & 25.4 & 19.2 & 118 & 21.1 & 21.5 & 330 \\
\hline Q6 & $\begin{array}{c}123 \\
33.6 \\
9.65\end{array}$ & $\begin{array}{r}101 \\
35.8 \\
12.0\end{array}$ & $\begin{array}{c}661 \\
225 \\
98.4\end{array}$ & $\begin{array}{l}81.6 \\
48.2 \\
21.9\end{array}$ & $\begin{array}{c}125 \\
30.2 \\
7.68\end{array}$ & $\begin{array}{r}1847 \\
558 \\
181\end{array}$ \\
\hline SDQ6 & 25.3 & 22.5 & 121 & 19.5 & 27.3 & 342 \\
\hline Q7 & $\begin{array}{c}153 \\
21.3 \\
6.99\end{array}$ & $\begin{array}{c}64.2 \\
20.0 \\
2.67\end{array}$ & $\begin{array}{c}428 \\
142 \\
58.4\end{array}$ & $\begin{array}{l}44.9 \\
26.4 \\
14.6\end{array}$ & $\begin{array}{c}47.1 \\
14.0 \\
3.03\end{array}$ & $\begin{array}{r}2453 \\
330 \\
125\end{array}$ \\
\hline SDQ7 & 22.6 & 14.5 & $\begin{array}{l}76.8 \\
-19\end{array}$ & 8.63 & 12.8 & 340 \\
\hline
\end{tabular}


Table 4.--Streamflow characteristics, in cubic feet per second, at selected streám-gaging stations (Continued)

Flow

Station name and site number

$\begin{array}{cccccc}\text { Kettle } & \begin{array}{c}\text { Quinsigamond } \\ \text { Brook }\end{array} & \begin{array}{c}\text { River at } \\ \text { Blackstone }\end{array} & \begin{array}{c}\text { Mumford } \\ \text { River at }\end{array} & \begin{array}{c}\text { West River } \\ \text { below West }\end{array} & \begin{array}{c}\text { Blackstone } \\ \text { River at }\end{array} \\ \text { at } & \text { North } & \text { River at } & \text { East } & \text { Hill Dam near } & \text { East } \\ \text { Worcester, } & \text { Grafton, } & \text { Northbridge, } & \text { Douglas, } & \text { Uxbridge, } & \text { Woonsocket, } \\ \text { Mass. } & \text { Mass. } & \text { Mass. } & \text { Mass. } & \text { Mass. } & \text { R. I. } \\ (3) & (10) & (11) & (14) & (19) & (36)\end{array}$

\section{MONTHLY (Continued)}

Q8

$$
\begin{gathered}
257 \\
21.2 \\
6.09
\end{gathered}
$$

SDQ8

33.6

Q9

156
24.5
5.16

SDQ9

26.7

8.5

2.2

4.9

.48

45

.81

30.0

11.0

62.0

15.0

22.5

25.1

37.0

56.8

86.4

77.0

111

124

188

335

558

102

YEARS

YRSDAY

54

40
41.

40
YRSLOW
38

25
32.8

24.7

11.6

6.72

34.8

24.7

14.4

6.09

$-$

2.8

134

1.5

101

35.8

9.75

2.14

2704

302

111

367

$18.6 \quad 1980$

$7.34 \quad 340$

$2.33 \quad 113$

4.58

316
6.6

2.0

93.0

11

2.9

130

15

3.8

160

22.5

8.6

249

25.1

11.3

287

37

27.6

523

56.8

61.9

987

86.4

114

1660 
Table 5.--Summary of 7-day low-flow characteristics, drainage area, and period of record for low-flow partial-record stations

(A dash indicates insufficient data are available to define 7Q10.)

\begin{tabular}{|c|c|c|c|c|c|c|}
\hline $\begin{array}{l}\text { Number } \\
\text { in } \\
\text { figure } \\
2\end{array}$ & $\begin{array}{l}\text { Station } \\
\text { number. }\end{array}$ & Station name & Location & $\begin{array}{l}\text { Period } \\
\text { of } \\
\text { record }\end{array}$ & $\begin{array}{l}\text { Drainage } \\
\text { area, } \\
\text { in } \\
\text { square } \\
\text { miles }\end{array}$ & $\begin{array}{l}\text { Estimated } \\
\text { annual minimum } \\
7 \text {-day mean } \\
\text { low flow, in } \\
\text { cubic feet per } \\
\text { second, at } \\
10 \text {-year } \\
\text { recurrence } \\
\text { interval }\end{array}$ \\
\hline 1 & 01109460 & $\begin{array}{l}\text { Ramshorn Book at } \\
\text { Auburn, Mass. }\end{array}$ & State Route 12 & $1978-79$ & 11.1 & 1.6 \\
\hline 4 & 01109540 & $\begin{array}{l}\text { Scott Brook near } \\
\text { Paxton, Mass. }\end{array}$ & South Road & $1978-79$ & 1.14 & .0 \\
\hline 5 & 01109850 & $\begin{array}{l}\text { Cold Spring Brook } \\
\text { at Wilkinsonville, } \\
\text { Mass. }\end{array}$ & $\begin{array}{l}\text { State Route } \\
122 \mathrm{~A}\end{array}$ & 1979 & 7.01 & - \\
\hline 6 & 01109851 & $\begin{array}{l}\text { Cold Spring Brook } \\
\text { tributary at } \\
\text { Wilkinsonville, } \\
\text { Mass. }\end{array}$ & $\begin{array}{l}\text { State Route } \\
122 \mathrm{~A}\end{array}$ & 1978 & .08 & - \\
\hline 7 & 01109870 & $\begin{array}{l}\text { Cronin Brook at } \\
\text { Wilkinsonville, } \\
\text { Mass. }\end{array}$ & - Folley Street & 1978 & 2.83 & .0 \\
\hline 8 & 01109920 & $\begin{array}{l}\text { Sewall Brook at } \\
\text { Morningdale, } \\
\text { Mass. }\end{array}$ & Mill Road Circle & 1978 & 3.47 & .4 \\
\hline 9 & 01109950 & $\begin{array}{l}\text { West Brook at } \\
\text { Shrewsbury, } \\
\text { Mass. }\end{array}$ & Main Street & 1978 & 2.08 & .0 \\
\hline 12 & 01110995 & $\begin{array}{l}\text { Whitin Reservoir } \\
\text { Outlet at } \\
\text { Manchaug, Mass. }\end{array}$ & Mumford Street & $1978-79$ & $\begin{array}{l}9.86 \\
:\end{array}$ & - \\
\hline 13 & 01110998 & $\begin{array}{l}\text { Centerville Brook } \\
\text { at East Douglas, } \\
\text { Mass. }\end{array}$ & West Street & 1978 & 3.74 & - \\
\hline 14 & 01111000 & $\begin{array}{l}\text { Mumford River at } \\
\text { East Douglas, } \\
\text { Mass. }\end{array}$ & $\begin{array}{l}100 \text { feet up- } \\
\text { stream from } \\
\text { Manchaug Road }\end{array}$ & ${ }^{1} 1978$ & $\begin{array}{c}29.1 \\
\quad \cdots \\
\quad .\end{array}$ & - \\
\hline
\end{tabular}


Table 5.--Summary of 7-day low-flow characteristics, drainage area, and period of record for low-flow partial-record stations (Continued)

\begin{tabular}{|c|c|c|c|c|c|c|}
\hline $\begin{array}{c}\text { Number } \\
\text { in } \\
\text { figure } \\
2\end{array}$ & $\begin{array}{l}\text { Station } \\
\text { number }\end{array}$ & Station name & Location & $\begin{array}{l}\text { Period } \\
\text { of } \\
\text { record }\end{array}$ & $\begin{array}{l}\text { Drainage } \\
\text { area, } \\
\text { in } \\
\text { square } \\
\text { miles }\end{array}$ & $\begin{array}{l}\text { Estimated } \\
\text { annual minimum } \\
7 \text {-day mean } \\
\text { low flow, in } \\
\text { cubic feet per } \\
\text { second, at } \\
10 \text {-year } \\
\text { recurrence } \\
\text { interval }\end{array}$ \\
\hline 15 & 01111130 & $\begin{array}{l}\text { Warren Brook near } \\
\text { West Upton, Mass. }\end{array}$ & Fowler Street & 1978 & 3.81 & 0.0 \\
\hline 16 & 01111150 & $\begin{array}{l}\text { West River at } \\
\text { West Upton, Mass. }\end{array}$ & Pleasant Street & 1978 & 14.7 & .5 \\
\hline 17 & 01111160 & $\begin{array}{l}\text { Center Brook at } \\
\text { Upton, Mass. }\end{array}$ & Hopkinton Road & 1978 & 2.10 & - \\
\hline 18 & 01111170 & $\begin{array}{l}\text { Center Brook at } \\
\text { Mendon Street, } \\
\text { Upton, Mass. }\end{array}$ & Mendon Street & $1978-79$ & 6.03 & $<.1$ \\
\hline 20 & 01111210 & $\begin{array}{l}\text { Still Corner } \\
\text { Brook near } \\
\text { Uxbridge, Mass. }\end{array}$ & Blackstone Street & 1978 & 1.28 & .0 \\
\hline 21 & 01111220 & $\begin{array}{l}\text { Laurel Brook near } \\
\text { Uxbridge, Mass. }\end{array}$ & Laurel Street & 1978 & 1.95 & .1 \\
\hline 23 & 01111272 & $\begin{array}{l}\text { Bating Brook near } \\
\text { Douglas, Mass. }\end{array}$ & Pine Street & 1968,1978 & $\begin{array}{ll}8 & 1.38\end{array}$ & .0 \\
\hline 24 & 01111273 & $\begin{array}{l}\text { Chase Pond } \\
\text { tributary near } \\
\text { Douglas, Mass. }\end{array}$ & Pine Street & 1968 & .77 & .0 \\
\hline 25 & 01111275 & $\begin{array}{l}\text { Tinkerville Brook } \\
\text { near Douglas, } \\
\text { Mass. }\end{array}$ & Round Top Road & $\begin{array}{l}1968 \\
1978-79\end{array}$ & 5.15 & $<.1$ \\
\hline 26 & 01111277 & $\begin{array}{l}\text { Round Top Brook } \\
\text { near Douglas, } \\
\text { Mass. }\end{array}$ & Orange Street & 1968 & .22 & .0 \\
\hline 27 & 01111290 & $\begin{array}{l}\text { Chockalog River } \\
\text { near Harrisville, } \\
\text { R.I. }\end{array}$ & $\begin{array}{l}200 \text { feet down- } \\
\text { stream from } \\
\text { Brook Road }\end{array}$ & 1968 & 4.15 & .0 \\
\hline 28 & 01112100 & $\begin{array}{l}\text { Mill River near } \\
\text { Milford, Mass. }\end{array}$ & State Route 140 & 1978 & 6.63 & .2 \\
\hline
\end{tabular}


Table 5.--Summary of 7-day low-flow characteristics, drainage area, and period of record for low-flow partial-record stations (Continued)

\begin{tabular}{|c|c|c|c|c|c|c|}
\hline $\begin{array}{c}\text { Number } \\
\text { in } \\
\text { figure } \\
2\end{array}$ & $\begin{array}{l}\text { Station } \\
\text { number }\end{array}$ & Station name & Location & $\begin{array}{l}\text { Period } \\
\text { of } \\
\text { record }\end{array}$ & $\begin{array}{l}\text { Drainage } \\
\text { area, } \\
\text { in } \\
\text { square } \\
\text { miles }\end{array}$ & $\begin{array}{c}\text { Estimated } \\
\text { annual minimum } \\
7 \text {-day mean } \\
\text { low flow, in } \\
\text { cubic feet per } \\
\text { second, at } \\
10 \text {-year } \\
\text { recurrence } \\
\text { interval }\end{array}$ \\
\hline 29 & 01112190 & $\begin{array}{l}\text { Muddy Brook at } \\
\text { South Milford, Mass }\end{array}$ & Bellingham Road & 1978 & 6.23 & 0.3 \\
\hline 30 & 01112200 & $\begin{array}{l}\text { Mill River at } \\
\text { South Milford, Mass }\end{array}$ & Bellingham Road & $1978-79$ & 19.1 & .7 \\
\hline 31 & 01112250 & $\begin{array}{l}\text { Mill River near } \\
\text { Blackstone, Mass. }\end{array}$ & Elm Street & 1978 & 25.3 & 1.5 \\
\hline 32 & 01112260 & $\begin{array}{l}\text { Hop Brook near } \\
\text { Blackstone, Mass. }\end{array}$ & Farm Street & 1978 & 2.76 & - \\
\hline 33 & 01112300 & $\begin{array}{l}\text { Bungay Brook near } \\
\text { Sheldonville, Mass. }\end{array}$ & Wrentham Street & ${ }^{2} 1965$ & 2.62 & - \\
\hline 34 & 01112350 & $\begin{array}{l}\text { Bungay Brook at } \\
\text { Crooks Corner, } \\
\text { Mass. }\end{array}$ & Wrentham Street & $1978-79$ & 3.84 & $<.1$ \\
\hline 35 & 01112380 & $\begin{array}{l}\text { Peters River at } \\
\text { Crooks Corner, } \\
\text { Mass. }\end{array}$ & Paine Street & $1978-79$ & 11.8 & .7 \\
\hline 37 & 01113670 & $\begin{array}{l}\text { Burnt Swamp Brook } \\
\text { near Grant Mills, } \\
\text { R.I. }\end{array}$ & Sumner Brown Rd. & 1978 & 4.68 & .0 \\
\hline 38 & 01113750 & $\begin{array}{l}\text { Abbott Run near } \\
\text { South Attleboro, } \\
\text { Mass. }\end{array}$ & Mendon Road & 1970 & 24.7 & - \\
\hline
\end{tabular}

\footnotetext{
${ }^{1}$ Daily flow record $1940-51$.
}

${ }^{2}$ Peak-flow site 1964-74. 


\section{SELECTED REFERENCES}

Benson, M. A., 1962, Factors influencing the occurrence of floods in a humid region of diverse terrain: U.S. Geological Survey Water-Supply Paper 1580B, 64 p.

Brackley, R. A. and Wandle, S. W., Jr., 1982, Drainage divides, Massachusetts--Nashua and Concord River basins: U.S. Geological Survey Open-File Report 82-924, 22 maps.

Halliwell, D. B., Kimball, W. A., and Screpetis, A. J., 1982, Massachusetts stream classification program, part I, Inventory of rivers and streams: Massachusetts Department of Environmental Quality Engineering and Department of Fisheries, Wildlife, and Recreational Vehicles, 126 p., appendix consisting of 3 pages.

Higgins, G. R., 1967, Yield of streams in Massachusetts: Amherst, Massachusetts, University of Massachusetts, Water Resources Research Center Publication 5, 175 p.

Hutchison, N. E., compiler, 1975, WATSTORE--National water data storage and retrieval system of U.S. Geological Survey--User's guide: U.S. Geological Survey Open-File Report 75-426, 791 p. (revised).

Johnson, C. G., 1970, A proposed streamflow data program for central New England: U.S. Geological Survey open-file report, 38 p., 1 appendix consisting of 11 pages.

Johnson, C. G., and Tasker, G. D., 1974, Progress report on flood magnitude and frequency of Massachusetts streams: U.S. Geological Survey Open-File Report 74-131, 41 p.

Johnston, H. E., and Dickerman, D. C., 1974a, Availability of ground water in the Blackstone River area, Rhode Island and Massachusetts: U.S. Geological Survey Water Resources Investigations 4-74, 2 pl.

$1974 \mathrm{~b}$, Availability of ground water in the Branch River area, Rhode Island and Massachusetts: U.S. Geological Survey Water Resources Investigations 18-74, 39 p., 1 pl.

Knox, C. E., and Nordenson, T. J., 1955, Average annual runoff and precipitation in the New England-New York area: U.S. Geological Survey Hydrologic Investigations Atlas 7, 6 p.

Knox, C. E., and Soule, R. M., 1949, Hydrology of Massachusetts, part 1, Summary of streamflow and precipitation records: U.S. Geological Survey Water-Supply Paper 1105, 240 p.

Krejmas, B. E., 1982, Drainage divides, Massachusetts-Blackstone and Thames River basins: U.S. Geological Survey Open-File Report 82-631, 12 maps.

Langbein, W. B. and Iseri, K. T., 1960, General introduction and hydrologic definitions, in Manual of hydrology, part 1, General surface-water techniques: U.S. Geological Survey WaterSupply Paper 1541-A, p. 1-29.

Langbein, W. B., and others, 1947, Topographic characteristics of drainage basins: U.S. Geological Survey Water-Supply Paper 968-C, p. 125-157.

Lautzenheiser, R. E., 1969, Snowfall, snowfall frequencies, and snow cover data for New England: Environmental Sciences Services Administration Technical Memorandum EDSTM 12, $15 \mathrm{p}$.

Male, J. W., and Ogawa, H., 1982, Low flows of Massachusetts streams: Amherst, Massachusetts, University of Massachusetts, Water Resources Research Center Publication 125, 152 p. 
Meeks, W. C., 1977, Daily values statistics (program A969), in Hutchison, N. E., compiler, 1975, WATSTORE--National water data storage and retrieval system of the U.S. Geological Survey user's guide: U.S. Geological Survey Open-File Report 75-426 (revised), chap. IV, section G.

Price, W. E., Jr., and Meeks, W. C., 1977, Daily values monthly and annual statistics (program W4422), in Hutchison, N. E., compiler, 1975, WATSTORE-National water data storage and retrieval system of the U.S. Geological Survey user's guide: U.S. Geological Survey Open-File Report 75-426 (revised), chap. IV, section F.

Riggs, H. C., 1971, Discussion of probability distribution of annual droughts by Eratakulan S. Joseph: American Society of Civil Engineers Proceedings, v. 97, no. IR3, p. 540-541.

1972, Low-flow investigations: U.S. Geological Survey Techniques of Water-Resources Investigations, book 4, chap. B1, $18 \mathrm{p}$.

Thomas, D. M., and Benson, M. A., 1970, Generalization of streamflow characteristics from drainage-basin characteristics: U.S. Geological Survey Water-Supply Paper 1975, 55 p.

U.S. Department of Agriculture, 1972, Soil Conservation Service National Engineering Handbook, section 4, Hydrology: U.S. Department of Agriculture, Soil Conservation Service.

U.S. Federal Inter-Agency River Basin Committee, Subcommittee on Hydrology, 1951, Interagency coordination of drainage area data, notes on hydrologic activities: Water Resources Council, Subcommittee on Hydrology Bulletin no. 4, 48 p.

U.S. Geological Survey, 1977, National handbook of recommended methods-for water-data acquisition: U.S. Geological Survey, chap. 7, 38 p.

1980, Water resources data for Massachusetts and Rhode Island, water year 1979: U.S. Geological Survey Water-Data Report MA-RI-79-1, 349 p.

U.S. Weather Bureau, 1959a, Climates of the states, Massachusetts: U.S. Weather Bureau, Climatography of the United States, Paper No. 60-19, 20 p.

$1959 \mathrm{~b}$, Rainfall intensity-frequency regime, northeastern United States: U.S. Weather Bureau Technical Paper no. 29, 35 p.

Walker, E. H., and Krejmas, B. E., 1983, Water resources in the Blackstone River basin, Massachusetts: U.S. Geological Survey Open-File Report 83-700, 37 p.

Wandle, S. W., Jr., 1982, Estimating peak discharges of small, rural streams in Massachusetts: U.S. Geological Survey Open-File Report 80-676, 33 p.

1983, Low-flow frequency and flow-duration analysis of natural-flow streams in Massachusetts: Boston Society of Civil Engineers Section Journal, v. 69, no 1, p. 87-110.

1984a, Gazetteer of hydrologic characteristics of streams in Massachusetts-coastal river basins of the North Shore and Massachusetts Bay: U.S. Geological Survey Water-Resources Investigations Report 84-4281.

$1984 \mathrm{~b}$, Gazetteer of hydrologic characteristics of streams in Massachusetts-Connecticut River basin: U.S. Geological Survey Water-Resources Investigations Report 84-4282.

$1984 \mathrm{c}$, Gazetteer of hydrologic characteristics of streams in Massachusetts-Hudson River basin: U.S. Geological Survey Water-Resources Investigations Report 83-4250. 
Wandle, S. W., Jr., and Fontaine, R. A., 1984, Gazetteer of hydrologic characteristics of streams in Massachusetts--Merrimack River basin: U.S. Geological Survey Water-Resources Investigations Report 84-4284.

Wandle, S. W., Jr., and Frimpter, M. H., 1982, Drainage divides, Massachusetts-Taunton River basin and southeast coastal basins: U.S.Geological Survey Open-File Report 82-870, 24 maps.

Wandle, S. W., Jr., and Keezer, G. R., 1984, Gazetteer of hydrologic characteristics of streams in Massachusetts-Taunton and Ten Mile River basins and coastal river basins of Mount Hope Bay, Narragansett Bay, and Rhode Island Sound: U.S. Geological Survey WaterResources Investigations Report 84-4283.

Wandle, S. W., Jr., and LeBlanc, J. A., 1984, Gazetteer of hydrologic characteristics of streams in Massachusetts-Thames River basin: U.S. Geological Survey Water-Resources Investigations Report 84-4287.

Wandle, S. W., Jr., and Lippert, R. G., 1984, Gazetteer of hydrologic characteristics of streams in Massachusetts--Housatonic River basin: U.S. Geological Survey Water-Resources Investigations Report 84-4285.

Wandle, S. W., Jr., and Morgan, M. A., 1984, Gazetteer of hydrologic characteristics of streams in Massachusetts--coastal river basins of the South Shore and Buzzards Bay: U.S. Geological Survey Water-Resources Investigations Report 84-4288. 
- N O T E S - 